\title{
FRAMEWORK OF VOCATIONAL SCHOOL AND UNIVERSITY OF APPLIED SCIENCES TEACHER ACTIVITIES: MOTIVATIONAL FACTORS, PROFESSIONAL ROLES AND APPLICATION OF EDUCATIONAL TECHNOLOGIES IN CORRELATION WITH PERSONALITY TRAITS
}

\begin{abstract}
Sigitas DAUKILAS, Centre for Cultural Communication and Education, Department of Philosophy, Psychology and Vocational Education, Aleksandras Stulginskis University, Universiteto st. 10, LT-53361 Akademija, Kaunas district, Lithuania, sigitas.daukilas@asu.lt (corresponding author)

Rita KEIBIENE், University of Applied Sciences, Pramonès pr. 20, LT-50468 Kaunas, Lithuania, rita.keibiene@go.kauko.lt

The relevance of this research is based on the standpoint of the epistemological methodology focusing on the quality of the profession cognition. Therefore, it is presumed that the quality of vocational education is determined by the variable personality traits of teachers (extraversion, openness towards experience and innovation, consciousness, agreeableness, neuroticism). The research object of the current study is the correlation between the personality traits of university of applied sciences teachers and vocational teachers and the curriculum components. The research aims at identifying the correlation between the motives of vocational school and university of applied sciences teacher activities, educational technologies they use, professional roles and their personality traits, as well as identifying the essential differences of the mentioned variables. The quantitative and qualitative research strategies were employed allowing the researchers to perceive and assess the parameters of the correlation between the professional identity of teachers, meaningfulness in pedagogical work, motivation and educational content.

The research results revealed that the social, extrinsic, introjected and identified regulation motivation in vocational schools and universities of applied sciences vary considerably; in universities of applied sciences social and identified regulation motivations manifest themselves, whereas in vocational schools a lot of demotivating factors related to the problems of vocational student identity, career prestige of a vocational teacher and external motivation, are observed. The role of vocational school and university of applied sciences teachers in the didactic process also varies: university of applied sciences lecturers identify themselves in the position of the teacher-andragogue, whereas vocational school teachers see their role as a professional (expert). Moreover, the principles of social constructivism in pedagogy and andragogy are more effective among university of applied sciences lecturers, while vocational school teachers often have to rely on the behaviouristic principles of pedagogy for educational assessment and the enhancement of student motivation.
\end{abstract}

Keywords: Vocational Schools, University of Applied Sciences, Teacher Activities, Motivational Factors, Professional Roles, Educational Technologies, Personality Traits

\section{INTRODUCTION}

The relevance of the study on the correlation between the curriculum constituents and teachers' personality traits is based on the fact that the communication, interactive cognition and reflection occurring during the pedagogicalandragogical interaction essentially determine the quality of the actual didactic process. First of all, it is related to the content of the relationship between a student (university of applied sciences student) and professional teacher (lecturer), which, in terms of quality, is described by the factors of interactive cognition, motivation, involvement into learning process, content personalisation and actuation. In 2016, scholars of Aleksandras Stulginskis University (Daukilas, Mičiulienė, Kovalčikienè, Kasperiūnienè, 2016) conducted the study on the vocational teacher activity content in Lithuanian vocational schools, which, in 2017, was carried out in universities of applied sciences as well. Such development strategy of the study on teacher activity content aims at identifying the key differences and similarities among the factors of teaching quality in the educational institutions of different types.

According to the data provided by the Ministry of Education and Science (SVIS, ŠMM, 2017), currently there are 3481 vocational teachers working and 47.6 thousand students studying in 74 Lithuanian vocational schools, while 37.6 students studying in 22 universities of applied sciences are taught by 1738 teachers. These numbers indicate that the general sample of persons teaching vocational subjects in Lithuanian vocational schools and universities of applied sciences is approximately 5000 .

Copyright (C) 2017 The Authors. Published by Aleksandras Stulginskis University. This is an open-access article distributed under the terms of the Creative Commons Attribution License (CC-BY 4.0), which permits unrestricted use, distribution, and reproduction in any medium, provided the original author and source are credited. 
The essential issue presented in this article is to determine how the personality traits of vocational teachers (consciousness, openness towards experience, agreeableness, extraversion, neuroticism) correlate with their work motives, educational methodology they use (educational technologies, evaluation strategies) and teachers' roles that directly influence the quality of profession cognition. The article also undertakes to identify the difference between the curriculum of vocational and university of applied sciences teachers. The research object of the current study is the correlation between the personality traits of teachers and the curriculum components. The research aims at identifying the correlation between the motives of vocational and university of applied sciences teacher activities, educational technologies they use, professional roles and their personality traits, as well as identifying the essential differences of the mentioned variables in vocational schools and universities of applied sciences. The research objectives are the following: 1. To discuss the motives of pedagogical-andragogical activity, the methodologies of the use of educational technologies and the strategies of quality curriculum in the context of teacher personalities. 2 . To analyse the motives of university of applied sciences teacher activity, their roles and the educational technologies they use in the context of personality traits and to compare them with the cases of vocational teachers.

The study employs naturalistic conception of human nature (Abromaitienè, Stanišauskienė, 2014; Smith, 2008), which has determined the methodological approach of this study. Even though both quantitative and qualitative research strategies were employed in the study, only the results of quantitative research were used for the analysis of the object of this article. The results of qualitative research were used in this article to describe and assess the parameters of the correlation between meaningfulness in pedagogical work and the quality of curriculum.

The quantitative research included 346 vocational teachers and 104 university of applied sciences teachers. The questionnaire of quantitative research consisted of 17 questions to identify facts and 22 opinion questions. To carry out the qualitative research, case analysis method was applied (Juodaityte, 2012), which allowed to identify the factors and prerequisites of evolution and change of variables, which are characteristic to the teachers of a certain personality type. The personality traits of teachers have been analysed by using The Big Five personality test (Beijaard, 2000).

\section{THE MOTIVES OF VOCATIONAL TEACHER ACTIVITIES, PROFESSIONAL ROLES AND EDUCATIONAL TECHNOLOGIES}

Studies by researchers (Targamadzè, 2014; Tulgan, 2013; Efe, Baysal, 2017) show that the role of teachers in the teaching process is conditioned by the changing teaching/learning paradigms and the circumstances of education / selfeducation of modern youth generation. The youth of today must be taught not only to discover the already known truths or use the experience shared by older generation, but also to create their personal and social realia by thinking critically, demonstrating their own cultural identity, being mobile, learning to live in a democracy. The researchers of teaching processes (Alaee, 2017; Masters, Freak, 2015; Sadovnikova, Sergeeva, Suraeva, 2016; Tran, Nguyen, 2013; Ubaque, Castañeda-Peña, 2017), claim that this situation determines the change of professional roles of educators (teachers), as they include more and more new components. First of all, it is related with educational environment of modern youth (Generation Z) as their visual, acoustic and communicational environment differs substantially from the environments of previous generations. The studies carried out by Tulgan (2013), Kasperiūnienè (2017) et al. demonstrate that the formation of modern generation takes place in a social media environment where both personal and non-personal relations may be established among people. Under these circumstances, there is a great gap observed between Generations $\mathrm{X}, \mathrm{Y}$, and $\mathrm{Z}$ in terms of technological competences since modern young people develop their own personal cognitive strategies in social media environment (Tulgan, 2013). Consequently, the work of older generation teachers (educators) becomes more and more complex, provoking various stressors and requiring more time and technological resources. Cirtautienė L. (2016) relates similar issues with the challenges of teachers' career motivation and identity, since, according to the author, "a positive, educational environment and its quality are determined by the personality of a teacher" (Cirtautiene், 2016).

Recently, Self-Determination Theory has been used to substantiate career goals of teachers (Gagne et al., 2015. Three types of motivation are discerned: intrinsic motivation, extrinsic motivation and amotivation, the latter referring to the absence of motivation towards an activity. Intrinsic motivation means engaging in the activity because of emotional satisfaction and pleasure (it is determined by personality traits of the teacher). Tijūnèlienè (2006) identifies intrinsic motivation with professional vocation and authority as being positive educational factors, highlighting the fact that "authority is the relationship" (Tijūnèlienè, 2006, p.48), which demonstrates the level of teacher's professional preparedness without violating the norms of pedagogical ethics, and helps attracting the attention of students with moral qualities. Thus, the teacher needs special pedagogical skills (communicative, organisational, expressive, etc.), as well as certain intellectual, moral and character traits (empathy, justice, tolerance), which are reflected in the motivational structure of the pedagogical work (the need to share the knowledge, spiritual and cultural values), and in developing students' personality powers and competences.

Extrinsic motivation of the teacher refers to those activities that are performed in order to achieve significant activity results such as receiving rewards and social approval, which are commonly referred to by various scholars as controlled motives (Wang, Hou, 2015). Self-Determination Theory specifies different sub-types of extrinsic motivation based on the level of self-regulation (Gagne et al., 2015), namely, social, material, introjected and identified regulation. Social regulation refers to expectations towards other significant people (expectations of becoming a professional authority, receiving approval, respect). Material regulation refers to the expectations of being rewarded, and identified regulation refers to an activity performed due to personal reasons of the teacher. Introjected regulation refers to the 
regulation of behaviour out of internally pressuring forces. This regulation differs from intrinsic motivation in that the activity is not performed out of inherent satisfaction, but for the instrumental value it represents. (Gagne et al., 2015).

The unstable demographic situation in the country, the processes of ongoing reforms and change are judged differently by vocational teachers and educational policy makers. Turčinskaitè - Andujar (2007) carried out the research on teachers' emotional and motivational reactions within working environment, which highlighted the fact that stability and safety of working environment are necessary for higher-order motivation. The author claims that with the increase in the need for security, the number of teachers fulfil self-actualisation at work significantly decreased, resulting in an increase in the number of those seeking to meet the basic needs. The same tendency is observed among persons who sought approval and who were motivated by people with lower-order needs. In this way, part of the teachers shifted from being motivation seekers to maintenance seekers.

In terms of educational methods used by vocational teachers and methodological positions in education, the curriculum of teachers has significantly changed over the last 10-20 years. It was not long ago that Hargreaves (1999) identified school as a formal institution, in which the work of the teacher was based on various teaching tasks performed in the system of human relations. In this context, the teacher's work usually meant classwork with students. Thirty years ago, Cypher, Willover (1984) described a similar situation regarding educational activities. They specified the following constituents of teacher activities: direct teaching, its organisation, analysis and evaluation of the cognitive process, examination and control of acquired competences. As a necessary condition for the educational process, they distinguished love for students, the desire to share knowledge and to teach and learn, as well as the desire to be significant and useful to the society. Important motivational factors are teacher's salary, social prestige, work stability, and security.

\section{THE FINDINGS OF RESEARCH ON UNIVERSITY OF APPLIED SCIENCES AND VOCATIONAL TEACHER ACTIVITY CONTENT}

The research findings are analysed in order to determine the correlation between the personality traits of vocational teachers, their motivational factors, the roles they play in vocational school or university of applied sciences and the educational technologies they use, as well as to reveal the key differences of researched variables in different types of educational institutions.

Activity motivation of vocational teachers (lecturers)

The comparative analysis of the correlation between university of applied sciences and vocational teachers' personality traits, activity motivation, professional roles and educational technologies they use showed that the parameters of teachers' expression vary in different types of educational institutions. The summary of the comparative analysis of research findings on university of applied sciences and vocational teachers' personality traits and activity motivation is provided in Table 1. The authors distinguish six components of teachers' work motivation, which show their correlation with the manifestation of teachers' extraversion, openness towards experience and innovation, consciousness, agreeableness, neuroticism. Specific components of teachers' work motivation are divided into extrinsic social and material, introjected and identified regulation, intrinsic motivation and amotivation groups.

Table 1 . The correlation of personality traits and activity motivation of university of applied sciences and vocational teachers

\begin{tabular}{|c|c|c|c|c|c|}
\hline \multirow{2}{*}{$\begin{array}{l}\text { The teachers' } \\
\text { work motivation } \\
\text { components }\end{array}$} & \multicolumn{2}{|c|}{ Personality traits } & \multirow[b]{2}{*}{ Consciousness } & \multirow{2}{*}{$\begin{array}{l}\text { Openness towards } \\
\text { experience and } \\
\text { innovation }\end{array}$} & \multirow[b]{2}{*}{ Neuroticism } \\
\hline & Extraversion & Agreeableness & & & \\
\hline $\begin{array}{r}\text { Extrinsic } \\
\text { (social motivation) }\end{array}$ & $\begin{array}{l}-0.038(\mathrm{VS}) \\
-0.123(\mathrm{C}) \\
\end{array}$ & $\begin{array}{l}-0.085(V S) \\
0.144(C) \\
\end{array}$ & $\begin{array}{l}-0.057(\mathrm{VS}) \\
-0.149(\mathrm{C}) \\
\end{array}$ & $\begin{array}{l}0.182 * *(\mathrm{VS}) \\
0.271 * *(\mathrm{C}) \\
\end{array}$ & $\begin{array}{l}0.022(V S) \\
-0.230 *(C)\end{array}$ \\
\hline $\begin{array}{c}\text { Extrinsic } \\
\text { (material motivation) }\end{array}$ & $\begin{array}{l}-0.221 * *(V S) \\
-0.164 * *(C)\end{array}$ & $\begin{array}{l}-0.159 * *(\mathrm{VS}) \\
0.155(\mathrm{C})\end{array}$ & $\begin{array}{l}-0.124 *(\mathrm{VS}) \\
-0.195(\mathrm{C}) \\
\end{array}$ & $\begin{array}{l}0.269 * *(\mathrm{VS}) \\
0.025(\mathrm{C})\end{array}$ & $\begin{array}{l}-0.123 *(\mathrm{VS}) \\
-0.255 *(\mathrm{C})\end{array}$ \\
\hline $\begin{array}{l}\text { Introjected } \\
\text { regulation }\end{array}$ & $\begin{array}{l}0.013(\mathrm{VS}) \\
0.220 *(\mathrm{C})\end{array}$ & $\begin{array}{l}0.062(\mathrm{VS}) \\
-0.029(\mathrm{C})\end{array}$ & $\begin{array}{l}0.054(\mathrm{VS}) \\
0.185(\mathrm{C})\end{array}$ & $\begin{array}{l}0.168^{* *}(\mathrm{VS}) \\
0.222^{*}(\mathrm{C})\end{array}$ & $\begin{array}{l}0.085 \text { (VS) } \\
0.066 \text { (C) }\end{array}$ \\
\hline $\begin{array}{l}\text { Identified } \\
\text { motivation }\end{array}$ & $\begin{array}{l}0.220^{* *}(\mathrm{VS}) \\
0.107(\mathrm{C})\end{array}$ & $\begin{array}{l}0.273^{* *}(\mathrm{VS}) \\
-0.260 *(\mathrm{C})\end{array}$ & $\begin{array}{l}0.274^{* *}(\mathrm{VS}) \\
0.246^{*}(\mathrm{C})\end{array}$ & $\begin{array}{l}-0.118 *(\mathrm{VS}) \\
0.222 *(\mathrm{C})\end{array}$ & $\begin{array}{l}0.244^{* *}(\mathrm{VS}) \\
0.117(\mathrm{C})\end{array}$ \\
\hline $\begin{array}{l}\text { Intrinsic } \\
\text { motivation }\end{array}$ & $\begin{array}{l}0.402^{* *}(\mathrm{VS}) \\
0.301^{* *}(\mathrm{C})\end{array}$ & $\begin{array}{l}0.337 * *(V S) \\
-0.324 *(C)\end{array}$ & $\begin{array}{l}0.345^{* *}(\mathrm{VS}) \\
0.088(\mathrm{C})\end{array}$ & $\begin{array}{l}-0.296 * *(\mathrm{VS}) \\
0.361 * *(\mathrm{C})\end{array}$ & $\begin{array}{l}0.405^{* *}(\mathrm{VS}) \\
0.254^{*}(\mathrm{C})\end{array}$ \\
\hline Amotivation & $\begin{array}{l}-0.242 * *(\mathrm{VS}) \\
-0.076(\mathrm{C}) \\
\end{array}$ & $\begin{array}{l}0.406 * *(V S) \\
0.257 *(C)\end{array}$ & $\begin{array}{l}-0.360^{* *}(\mathrm{VS}) \\
-0.189(\mathrm{C}) \\
\end{array}$ & $\begin{array}{l}0.282 * *(\mathrm{VS}) \\
-0.095(\mathrm{C}) \\
\end{array}$ & $\begin{array}{l}-0.186 * *(\mathrm{VS}) \\
-0.300 *(\mathrm{C}) \\
\end{array}$ \\
\hline
\end{tabular}

The correlation strength of the dependence of teachers' personal traits on activity motives provided in the table is assessed by using Kendall $\mathrm{tau}_{\text {tb }}$ on an ordinal scale, and by using Contingency coefficient (C) statistics on the nominal scale. The differences described in the text are statistically significant (significance threshold $\mathrm{p}<0.05, \mathrm{p}<0.01$ ). The analysis revealed similar tendencies in the manifestation of extraversion, consciousness and neuroticism of university of applied sciences and vocational teachers. The majority of correlation differences in the environment of teachers working in educational institutions are observed in the cases of agreeableness traits and all work motivation components, since the agreeableness trait represents social interest as well as dominant interpersonal relationship between a teacher and a student. In case of university of applied sciences teachers, negative correlation of intrinsic motivation $(-0,324 *)$ shows that the working environment of university of applied sciences teachers features more interpersonal relationship issues 
related to competitive relationships and self-discipline. The correlations of agreeableness trait and intrinsic motivational factors are quite strong $(0,337 * *)$ in vocational schools, which shows a rather high level of dutifulness and organisational skills of teachers. Furthermore, the teachers with strongly expressed agreeableness traits experience career demotivating factors (dissatisfaction $(-0,360 * *)$, stressors $\left(-0,186^{* *}\right)$ ).

When hypothetically assessing the extrinsic (material) motivational parameters it was expected that there should be no significant differences between the environments of universities of applied sciences and vocational schools. However, the research showed that this motivation is equally inherent to non-extrovert teachers that are more reserved and distant. Different from universities of applied sciences, the environment of vocational school teachers is characterised by a less expressed relation between agreeableness trait and material motivation $(-0.159 * *$ in vocational schools and 0.155 in universities of applied sciences), while the manifestation of correlation between neuroticism and extrinsic motivation is more characteristic to vocational school teachers.

Main roles of vocational teachers

The research results of the roles of vocational teachers display dominant tendencies of didactic (educational) systems or paradigms in different types of educational institutions. University of applied sciences lecturers as well as vocational school teachers usually take the role of a teacher, motivator, mentor, educator and mentor of moral education in the actual didactic process. (see Figure 1).

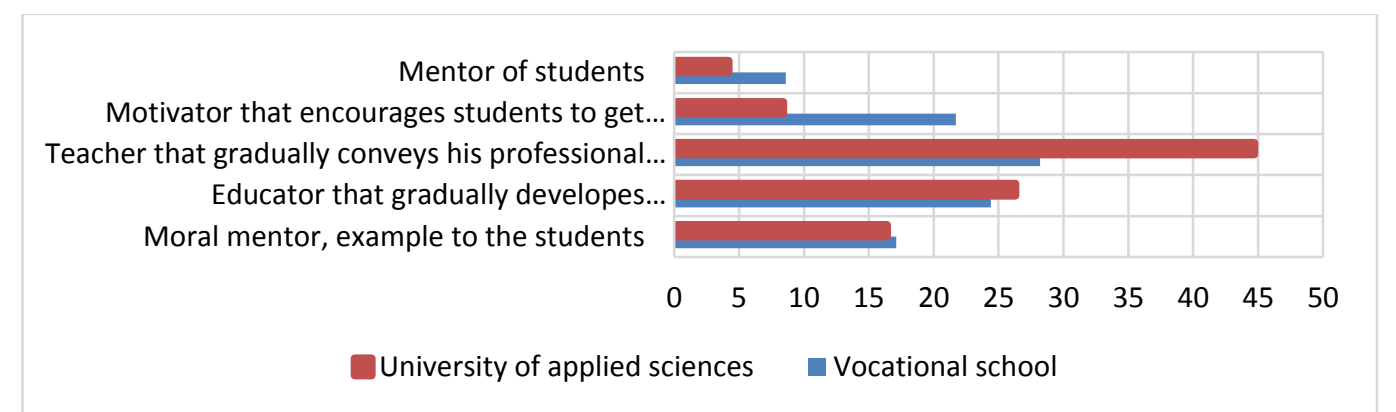

Figure 1. Distribution of roles of university of applied sciences and vocational school teachers in the didactic process

The research revealed that the roles of vocational school teachers and university of applied sciences lecturers vary. The statistically significant difference in assessing the activity content components (activities) of university of applied sciences and vocational school teachers is observed in subject curriculum. Thus, in didactic process, vocational teachers usually focus not on the pedagogical interaction but on the subject content. Greater concentration of lecturers' activities focusing on subject content can be viewed in universities of applied sciences. 44.7 per cent of university of applied sciences lecturers view the subject content as a priority activity. The second place in the order of priority is taken by the activity of gradual vocational education (26.3 per cent of respondents).

In the environment of vocational schools, the situation is different. Here three roles of vocational teachers can be clearly distinguished: a teacher that develops vocational competencies and transfers his knowledge to students (18.2 per cent of respondents); an educator that gradually develops the vocational power of students (24.4 per cent) and a motivator that encourages students to get acknowledged with their profession (21.7 per cent). Activities that are appreciated the least are of the mentor, organiser of after-school activities (8.6 per cent) and mentor of moral education (17.1 per cent). The results of this researched variable reflect that the problems of value education are not relevant in the university of applied sciences environment in comparison to the vocational school environment. In addition, these findings are supported by the gained reliable correlations between the personality traits and the priority of the subject curriculum in the environment of university of applied sciences teachers (see Table 2).

Table 2. The correlation of dominant roles of university of applied sciences teachers with their personality traits

\begin{tabular}{|c|c|c|c|c|c|}
\hline \multirow{2}{*}{$\begin{array}{l}\text { Dominant roles of university of } \\
\text { applied sciences teachers in the } \\
\text { educational process }\end{array}$} & \multicolumn{5}{|c|}{ Personality traits } \\
\hline & Extraversion & Neuroticism & Consciousness & $\begin{array}{l}\text { Openness towards } \\
\text { experience and } \\
\text { innovations }\end{array}$ & Agreeableness \\
\hline $\begin{array}{l}\text { The significance of gradual } \\
\text { development of students' } \\
\text { personality (the role of teacher- } \\
\text { andragogue) }\end{array}$ & $\begin{array}{l}0.223 \\
(p=0.030)^{*}\end{array}$ & $\begin{array}{l}-0.282 \\
(p=0.006) * *\end{array}$ & $\begin{array}{l}0.215 \\
(p=0.037)^{*}\end{array}$ & $\begin{array}{l}0.452 \\
(\mathbf{p}<0.001)^{* * *}\end{array}$ & $0.085(\mathrm{p}=0.415)$ \\
\hline $\begin{array}{l}\text { I focus on the development of } \\
\text { competencies of the taught subject }\end{array}$ & $\begin{array}{l}0.159 \\
(\mathrm{p}=0.124)\end{array}$ & $\begin{array}{l}-0.213 \\
(\mathrm{p}=0.038) *\end{array}$ & $\begin{array}{l}\mathbf{0 . 2 1 7} \\
(\mathrm{p}=\mathbf{0 . 0 3 5}) *\end{array}$ & $0.211(p=0.041)^{*}$ & $0.211(\mathrm{p}=0.040)^{*}$ \\
\hline
\end{tabular}

Notes: $* * \mathrm{p}<0.01 ; * \mathrm{p}<0.05$.

Therefore, university of applied sciences teachers have more favourable circumstances of didactic process in identifying themselves in the position of experts of their taught subject. Here the priority role falls on the constant vocational development in the field of the taught subject. By comparing this position with the dominant roles of vocational school teachers, in this case the teacher takes not the role of an expert of his subject but the role of the organiser of pedagogical interaction in developing professional competencies of the student. 


\section{Employed educational technologies}

During the research, correlations between the personality traits of teachers and employed traditional and modern educational technologies were established. During the research it was revealed (see Table 3) that modern educational technologies are usually employed by those teachers that are open towards experience and innovations.

Table 3. The correlation of educational technologies employed by university of applied sciences teachers that teach vocational subjects and the correlation between assessment strategies and personality traits

\begin{tabular}{|l|c|c|c|c|c|}
\hline \multirow{1}{*}{$\begin{array}{c}\text { Educational tools based } \\
\text { on modern technologies }\end{array}$} & \multicolumn{2}{|c|}{ Personality traits } \\
\cline { 2 - 6 } & Extraversion & Neuroticism & Consciousness & $\begin{array}{c}\text { Openness } \\
\text { towards } \\
\text { experience }\end{array}$ & Agreeableness \\
\hline $\begin{array}{l}\text { Google Scholar and electronic } \\
\text { databases }\end{array}$ & 0.201 & 0.128 & 0.121 & $\mathbf{0 . 2 9 8} * *$ & $\mathbf{- 0 . 2 6 4} * *$ \\
\hline $\begin{array}{l}\text { Video material (CD-DVD, } \\
\text { Youtube) }\end{array}$ & 0.080 & 0.109 & -0.025 & 0.134 & $\mathbf{- 0 . 2 2 4} *$ \\
\hline $\begin{array}{l}\text { Virtual and augmented reality } \\
\text { solutions }\end{array}$ & 0.108 & 0.029 & -0.040 & $\mathbf{0 . 2 9 2} * *$ & -0.117 \\
\hline
\end{tabular}

Personality traits

\begin{tabular}{|c|c|c|c|c|c|}
\hline \multicolumn{6}{|c|}{ Personality traits } \\
\hline $\begin{array}{l}\text { Assessment strategies of } \\
\text { academic achievements }\end{array}$ & Extraversion & Neuroticism & Consciousness & $\begin{array}{l}\text { Openness } \\
\text { towards } \\
\text { experience }\end{array}$ & Agreeableness \\
\hline $\begin{array}{l}\text { I use an academic assessment } \\
\text { system }\end{array}$ & 0.161 & -0.168 & $0.234 *$ & $0.269 * *$ & -0.028 \\
\hline $\begin{array}{l}\text { Application of development of } \\
\text { critical thinking methods }\end{array}$ & -0.045 & $-0.221 *$ & $0.275 * *$ & $\mathbf{0 . 2 7 7} * *$ & 0.140 \\
\hline & \multicolumn{5}{|c|}{ Personality traits } \\
\hline $\begin{array}{l}\text { Tools applied to assess } \\
\text { academic achievements of } \\
\text { students }\end{array}$ & Extraversion & Neuroticism & Consciousness & $\begin{array}{l}\text { Openness } \\
\text { towards } \\
\text { experience }\end{array}$ & Agreeableness \\
\hline I present the assessments orally & -0.016 & -0.074 & 0.183 & $0.245 *$ & 0.029 \\
\hline I use IT tools for the assessment & -0.174 & 0.074 & 0.127 & $\mathbf{0 . 4 3 3} *$ & -0.064 \\
\hline
\end{tabular}

According to the activity content of vocational school teachers, their technological priorities are different. Vocational teachers allocate most of their efforts to educational technologies that are "oriented towards students" (24.4 per cent of respondents) than to those strategies that "correspond to teaching standards" ( 20.2 per cent of respondents) and profitable educational strategies (12.6 per cent of respondents) that are implemented by using IT.

\section{CONCLUSIONS}

Various educational quality strategies are applied in the methodology and practice of vocational training. In the sense of acknowledging profession (epistemological sense) by assessing the factors of educational quality, the personality traits of teachers as well as their professional, didactic and pedagogical identity take priority positions. Thus, the quality of vocational education is significantly determined by personality traits of lecturers and vocational teachers: extraversion, openness towards experience and innovations, consciousness, agreeableness and neuroticism. By conducting this research on correlation between personality traits of university of applied sciences and vocational school teachers and components of their educational content it was revealed that:

1. The external social and material motivation as well as motivation of introjected and identified regulation differ in vocational schools and universities of applied sciences: in universities of applied sciences social motivation and identified regulation motivation are more expressed, whereas in vocational schools many existing demotivating factors deal with the problems of students' vocational identity as well as teacher's career status and extrinsic material motivation.

2. The roles that vocational school and university of applied sciences teachers play in didactic process also differ: university of applied sciences teachers associate their identity with the identity of an expert of their taught subject, as in the didactic process the main focus is given to the educational content of the subject. The dominant role of vocational school teachers is related not to the expert competency but to the role of an organiser of pedagogical interaction in developing vocational competencies of students.

3. Tendencies of educational technologies employed in universities of applied sciences and vocational schools reveal that universities of applied sciences usually apply educational technologies based on social constructivist and connectivist pedagogy. Due to the problems of motivation to study, educational technologies that are based on behaviourist methodology as well as educational assessment of student competencies are widely used.

\section{REFERENCES}

1. Alaee, M. 2017. Investigating the Relationship between Multiple Intelligences and Professional Identity of Iranian EFL Teachers. Journal of Pan-Pacific Association of Applied Linguistics, 21p. 
2. Abromaitienè, L., Stanišauskienè, V. 2014. Profesinis perdegimas karjeros raidos kontekste: ikimokyklinio ugdy pedagogų atvejis. Andragogika, Vol. 1 (5), pp. 10-26.

3. Beijaard, D., Verloop, N., Vermunt, J.D. 2000. Teachers' perceptions of professional identity: an exploratory study from a personal knowledge perspective. Teaching and Teacher Education, Vo. 16, pp. 749-764. https://doi.org/10.1016/S0742-051X(00)00023-8

4. Bruce Tulgan 2013. Meet Generation Z: The second generation within the giant "Millennial" cohort. RainmakerThinking, Inc.

5. Cypher T., Willover D.J. 1984. The work behavior of secondary school teacher. Journal of Research and Development, No.18.

6. Daukilas, S., Mičiulienè, R., Kovalčikienè, K., Kasperiūnienė J. 2016. Profesijos pedagogu veiklos turinys. Tobulejimas, identitetas, ugdymo turinio metodologija ir kokybe. Monografija. Kaunas, Akademija, 320 p.

7. Efe, H. A., Baysal, Y. E. 2017. Determining Science Teachers' Levels of Motivation and Self-Regulation Regarding Use of Education Technologies. European Journal of Education Studies, Vol. 3(6), pp. 329-354.

8. Eryilmaz, A. 2014. Perceived Personality Traits and Types of Teachers and Their Relationship to the Subjective Well-Being and Academic Achievements of Adolescents. Educational Sciences: Theory and Practice, Vol. 14(6), pp. 2049-2062.

9. Europos Komisijos komunikatas „2020 m. Europa“. eur-lex.europa.eu/legal-content/LT/TXT/?uri=CELEX\%3A52010DC2020

10. Gagne, M., Forest, J., Vansteenkiste, M., Crevier-Braud, L., van den Broeck, A., Aspeli, A. K., Bellerose, J., Benabou, Ch., Chemolli, E., Guntert, S. T., Halvari, H., Indiyastuti, D. L., Johnson, P. A., Molstad, M. H., Naudin, M., Ndao, A., Olafsen, A. H., Roussel, P., Wang, Z., Westbye, C. 2015. The Multidimensional Work Motivation Scale: Validation evidence in seven languages and nine countries. European Journal of Work and Organizational Psychology, Vol. 24(2), pp. $178-196$. https://doi.org/10.1080/1359432X.2013.877892

11. Hargreaves A. 1999. Keičiasi mokytojai, keičiasi laikai. Vilnius. Margi raštai. [In Lithuanian]

12. Juodkūnè, I. 2015. Pedagogų asmenybès bruožų ịtaka savideterminacijai. Pedagogika, pp. $46-63$. https://doi.org/10.15823/p.2015.066 [In Lithuanian]

13. Juodaitytè, A. 2012. Kokybiniai edukaciniai tyrimai: teorijos, duomenu rinkimas ir analizè. Mokslo studija. ŠU leidykla, 416 p. [In Lithuanian]

14. Kasperiūnienè, J. 2017. Univerrsity teachers and their students self-regulated learning in social networks. Summary of doctoral disertation. Kaunas, VMU, 50 p.

15. Kavaliauskienė, V. 2001. Pedagoginis pašaukimas ir jo ugdymas. Klaipėda: Klaipėdos universiteto leidykla. [In Lithuanian]

16. Lietuvos pažangos strategija „Lietuva 2030“;

17. Lietuvos švietimas skaičiais 2016. Studija, Mokslo ir studijų stebėsenos ir analizės centras, Vilnius, 71 p. (http://www.svis.smm.lt/) (Accessed on 2017/10/02) [In Lithuanian]

18. Marshall, G., Kiffin-Petersen, S., Soutar, G. 2012. The Influence Personality and Leader Behaviours Have on Teacher SelfLeadership in Vocational Colleges. Educational Management Administration \& Leadership, Vol. 40(6), pp. $707-723$. https://doi.org/10.1177/1741143212456910

19. Masters, Y., Freak, A. 2015. Grappling with Multiplicity: A Framework for Teacher Formation. Australian Journal of Teacher Education, 40(12), 14-26. https://doi.org/10.14221/ajte.2015v40n12.2

20. Milkintaitè, L. 2001. Mokytojo asmenybė ir pedagoginio darbo motyvacija. Pradinis ugdymas Nr.2, Šiauliai. Šiaulių universiteto leidykla [In Lithuanian]

21. Mintrop, R., Ordenes, M. 2017. Teacher Work Motivation in the Era of Extrinsic Incentives: Performance Goals and Pro-Social Commitments in the Service of Equity. Education Policy Analysis Archives, Vol. 25(44), 43 p. https://doi.org/10.14507/epaa.25.2482

22. Paleksić, V., Narić, S., Vukotić, M., Stankovć, S. 2017. The Relationship between Personality Traits and Job Satisfaction of Teachers. Scripta Medica, Vol. 48(1), pp. 11-16. https://doi.org/10.18575/msrs.sm.e.17.02

23. Sadovnikova, N.O., Sergeeva, T.B., Suraeva, M.O. 2016. Phenomenological Analysis of Professional Identity Crisis Experience by Teachers. International Journal of Environmental and Science Education, Vol. 11(14), pp. 6898-6912.

24. Smith, M., ir kt. 2008. Preventing burnout: signs, symptoms, causes, and coping strategies. Taylor and Francis.

25. Stoškus, A. 2011. Kūno kultūros mokytojų profesinio perdegimo ypatumai. Tiltai, No. 3, p. 191-199. [In Lithuanian]

26. SVIS. www.svis.smm.lt/

27. Tentama, F., Pranungsari, D. 2016. The Roles of Teachers' Work Motivation and Teachers' Job Satisfaction in the Organizational Commitment in Extraordinary Schools. International Journal of Evaluation and Research in Education, Vol. 5(1), pp. $39-45$.

28. Tran, L.T., Nguyen, N.T. 2013. Mediating Teacher Professional Identity: The Emergence of Humanness and Ethical Identity. International Journal of Training Research, Vol. 11(3), pp. 199-212. https://doi.org/10.5172/ijtr.2013.11.3.199

29. Turčinskaitè - Andujar A. 2007. Pedagogų emocinès ir motyvacinès reakcijos darbo aplinkos momentiniu pokyčiu kontekste: Lietuvos švietimo reformos atvejis. Socialiniai mokslai, Vol. 2 (56). KTU.

30. Ubaque, D. F., Castañeda-Peña, H. 2017. Teacher Research: Uncovering Professional Identities and Trajectories of Teacher Researchers through Narrative Research-A Colombian Case. International Education Studies, Vol. 10(3), pp. 35-45. https://doi.org/10.5539/ies.v10n3p35

31. Vilija Targamadzè, V., Girdzijauskienė S., Šimelionienė A., Pečiuliauskienė P., Nauckūnaitė Z. 2015. Naujoji (Z) karta-prarastoji ar dar neatrastoji. Mokslo studija, Vilnius. [In Lithuanian] 